\title{
The relationship of silage temperature with the microbiological status of the face of corn silage bunkers
}

\author{
G. Borreani ${ }^{1}$ and E. Tabacco \\ Dipartimento di Agronomia, Selvicoltura e Gestione del Territorio, University of Torino, 10095 Grugliasco (Torino), Italy
}

\begin{abstract}
A method is proposed to quantify aerobic deterioration of corn silage forage quality as related to the temperature of silage mass in the bunker. Aerobic deterioration, apart from causing nutritional value losses, affects the hygienic quality of silages through the accumulation of pathogenic organisms and their toxins. A survey was carried out in northern Italy that involved a detailed examination of silage bunker from each of 54 dairy farms. Samples from the core, the peripheral areas within $1 \mathrm{~m}$ from the silo walls, and the molded spots, when present, were collected. The sample and silage temperatures across the working face were measured at depths of $200 \mathrm{~mm}$ at 11 locations and at 7 elevations. The temperature of the central zone of the silo was defined as the reference temperature $\left(\mathrm{T}_{\text {ref } 40}\right)$. The difference between the temperature of the silage sample and the $T_{\text {ref } 40}$ was used as a heating index associated with aerobic deterioration $\left(\mathrm{dT}_{\text {ref40 }}\right)$. The working face area with visible molds was measured. The samples were analyzed for DM content; $\mathrm{pH}$; water activity; nitrates; lactic, acetic, and butyric acids; and microbiological count of yeasts, molds, and clostridia spores. The core samples always showed a $\mathrm{pH}$ below 4.0 and a $\mathrm{dT}_{\text {ref } 40}$ below $2^{\circ} \mathrm{C}$, whereas the silages from the peripheral areas were split into 2 groups, one that had a $\mathrm{pH}$ lower than 4 and a $\mathrm{dT}_{\text {ref } 40}$ lower than $3.5^{\circ} \mathrm{C}(53 \%)$ and one that had a $\mathrm{pH}$ higher than 4 and a $\mathrm{dT}_{\text {ref } 40}$ higher than $5^{\circ} \mathrm{C}(47 \%)$. Most of the silages from the peripheral areas (94\%) and all the silages from the moldy spots that have a $\mathrm{dT}_{\text {ref40 }}$ above $5^{\circ} \mathrm{C}$ had a $\mathrm{pH}$ higher than 4.5 . Furthermore, a positive $\mathrm{dT}_{\text {ref40 }}$ higher than $5^{\circ} \mathrm{C}$ corresponds to a higher yeast count than $5 \log \mathrm{cfu} / \mathrm{g}$ in most of the silages from the peripheral areas (93\% of samples) and in almost all the silages from the molded spots. The evaluation of the extension of the visible molded areas combined with temperature measurement at $200 \mathrm{~mm}$ behind the feed-out face could offer a good indication of the health status of silage during consumption. Furthermore, this
\end{abstract}

Received November 18, 2009.

Accepted February 20, 2010.

${ }^{1}$ Corresponding author: giorgio.borreani@unito.it method could be useful to detect early stages of the aerobic deterioration process and to improve silage management.

Key words: aerobic deterioration, silage temperature, yeast count, mold count

\section{INTRODUCTION}

Silage produced from corn is the major source of forage for lactating dairy cows in Europe and North America. Most of the silage stored in horizontal silos is exposed to air penetration, especially in the upper parts near the walls, which are difficult to pack and seal properly (Ashbell and Lisker, 1988). Much greater losses can occur, however, when a silo is opened for feeding caused by aerobic microorganisms that use the DM as a source of energy (Rees, 1982). Oxygen enables various aerobic spoilage microorganisms to become active and to multiply, causing aerobic deterioration (Woolford, 1990). Aerobic deterioration usually results in high DM loss (Bolsen et al., 1993) and the loss of important nutritional components (Kung et al., 1998). Aerobic deterioration of silage not only causes nutritional value losses (Whitlock et al., 2000), it also negatively affects the hygienic quality of silages because of the increased risk of proliferation of potentially pathogenic or otherwise undesirable microorganisms, such as molds, bacilli, and Listeria monocytogenes (Lindgren et al., 2002). Such activities result in the accumulation of pathogenic organisms and their toxins in the silage, with effects on animal and human health (Ivanek et al., 2006; Vissers et al., 2007), the accumulation of degradation products, and the transmission of organisms that negatively affect food quality (Wilkinson, 1999; Tabacco et al., 2009). Lactic acid, acetic acid, and water-soluble carbohydrates are the main sources of energy for the microorganisms involved in the first phase of silage deterioration (McDonald et al., 1991). The oxidation of these nutrients results in the production of carbon dioxide and water, with the evolution of heat and an increase in silage $\mathrm{pH}$ (McDonald et al., 1991). On the farm, this deterioration is usually manifested by an increase in temperature and by the appearance of molds in the peripheral areas of the silo (Ashbell and 
Weinberg, 1992). Silages that spoil and heat in the bunker or in the feed bunk may dramatically affect daily DMI because cows are reluctant to consume unstable silages, especially during the warm season when DMI is already compromised (Mahanna and Chase, 2003).

Because the evaluation of microbiological and chemical quality of the working face of a silage during the feed-out phase would require many samples, expensive labor and equipment, qualified personnel, and timeconsuming laboratory analyses, a simple method is necessary to accurately and quickly assess silage quality. The aim of the study was to find a correlation between the microbial and chemical composition of silage during the feed-out phase and some easily measurable parameters to enable technicians and farmers to quantify the extent of aerobic deterioration at the farm level. A commercial farm survey was conducted to 1) compare the temperature at the feed-out face to silage $\mathrm{pH}$, yeast and mold activity, and lactic acid concentration, and 2) to quantify the extent of aerobic deterioration through silage thermography and surface covered by visible molds.

\section{MATERIALS AND METHODS}

A survey was carried out in the western Po Plain (Italy) on 54 dairy farms with Italian Friesian cows. Farms performing well, moderately well, and poorly were selected to ensure that not only high-quality silages were surveyed. Different farm enterprises and a range of ensiling practices were examined. One corn silage bunker that had been open for at least $20 \mathrm{~d}$ was examined in detail on each farm. The silages were ensiled in bunker silos and were covered with at least 1 polyethylene sheet. The width of the sampled silages ranged from 5.3 to $11.5 \mathrm{~m}$, the height from 1.5 to $3.3 \mathrm{~m}$, and silage densities in the core from 535 to $713 \mathrm{~kg} / \mathrm{m}^{3}$. The daily feed-out rates ranged from 7 to $25 \mathrm{~cm}$ in the winter period and from 8 to $33 \mathrm{~cm}$ in summer. Samples from the silage core, from the peripheral areas, and, where present, from visible molded spots were taken from the feed-out face of each silo to determine the fermentation characteristics, $\mathrm{pH}, \mathrm{DM}$ content, yeast and mold count, and clostridia spore concentration. Before coring, the temperatures were measured within the stored silages during feed-out at a depth of $200 \mathrm{~mm}$ into the working face, in the same place where the samples were taken, using a digital thermometer (Testo 925, Hotek Technologies Inc., Tacoma, WA) equipped with a 600or 1,200-mm fast-action thermocouple probe $(5 \mathrm{~mm}$ diameter). The core and the peripheral area samples were taken using a steel corer ( $45 \mathrm{~mm}$ diameter) to a depth of about $200 \mathrm{~mm}$. Two core samples were taken in the middle of the silo (108 samples in total) and 2 from the peripheral areas with no visible mold (within $1 \mathrm{~m}$ from the silo walls and $0.40 \mathrm{~m}$ from the top; 108 samples in total). A grab sample of about $0.5 \mathrm{~kg}$ was taken from up to 3 visibly molded spots, when present (153 samples in total).

The core depth (about $200 \mathrm{~mm}$ ) and weight were measured to determine the silage density (Muck and Holmes, 2000). The temperatures were measured in the same silos inside the stored silages during feed-out at a depth of $200 \mathrm{~mm}$ from the working face. Measurements were taken at 11 locations across the working face $(0.25,0.5,1.0,2.0$, and $3.0 \mathrm{~m}$ from both the right and left side walls and in the middle of the silo face) and at 7 elevations $(0.1,0.2,0.3,0.6,1.0$, and 2.0 below the top surface and $0.2 \mathrm{~m}$ above the base), as reported by Borreani and Tabacco (2009). Ambient temperature was recorded at the same time. The working face area with visible molds was also determined and measured. The central silo zone temperature $(\mathrm{h} / 2$ and $\mathrm{x} / 2$, where $\mathrm{h}=$ height of the silo and $\mathrm{x}=$ width of the silo) was measured at depths of 200,400,600, and 1,200 mm from the working face and defined as the reference temperature $\left(\mathbf{T}_{\text {ref }}\right)$. The difference between the silage sample temperature and the $\mathrm{T}_{\text {ref }}$ was used as an index of heating associated with aerobic deterioration $\left(\mathbf{d T}_{\text {ref }}\right)$. The climatic patterns of the western Po Plain (latitude from $45^{\circ} 40^{\prime} \mathrm{N}$ to $44^{\circ} 40^{\prime} \mathrm{N}$; $1977-2008$ period) were characterized by mean daily temperature increases of $0.6^{\circ} \mathrm{C}$ in January to $22.1^{\circ} \mathrm{C}$ in July [average minimum January temperature $=-3.8^{\circ} \mathrm{C}$ (lowest $=-17.8^{\circ} \mathrm{C}$ ) and average maximum July temperature $=28.5^{\circ} \mathrm{C}$ (highest $\left.\left.=38.0^{\circ} \mathrm{C}\right)\right]$.

\section{Sample Preparation and Analyses}

The silage samples were split into 2 subsamples. One subsample was oven-dried at $60^{\circ} \mathrm{C}$ for $72 \mathrm{~h}$ to determine the DM content, air equilibrated, weighed, and ground in a Cyclotec mill (Tecator, Herndon, VA) to pass a 1-mm screen. The dried silage samples were analyzed for total nitrogen, according to the Dumas method (Schindler and Knighton 1999), using a nitrogen analyzer Micro-N (Elementar, Hanau, Germany). The second subsample was stored as a wet sample at $-30^{\circ} \mathrm{C}$. Wet samples were extracted using a stomacher blender (Seward Ltd., Worthing, UK) for 4 min in distilled water at a ratio of water to sample material (fresh weight) of 9:1 or in $\mathrm{H}_{2} \mathrm{SO}_{4}(0.05 \mathrm{~mol})$ at a ratio of acid to sample material (fresh weight) of 5:1. The nitrate $\left(\mathrm{NO}_{3}\right)$ contents were determined in the water extract through semiquantitative analysis using Merckoquant test strips (detection limit $=100 \mathrm{mg}$ of $\mathrm{NO}_{3} / \mathrm{kg}$ of fresh matter; Merck, Darmstadt, Germany). The ammonia nitrogen $\left(\mathrm{NH}_{3}-\mathrm{N}\right)$ content, determined using a specific 
electrode, was quantified in the water extract. The lactic and monocarboxylic acids (acetic, propionic, and butyric acids) were determined by HPLC in the acid extract (Canale et al., 1984). Duplicate analyses were performed for all the determined parameters. The duplicates were averaged and the means were considered as observations in the statistical analysis. The water activity $\left(\mathbf{a}_{\mathrm{w}}\right)$ of the silage was measured at $25^{\circ} \mathrm{C}$ using an AquaLab Series 3TE (Decagon Devices Inc., Pullman, WA) that used the chilled-mirror dew point technique on a fresh sample.

To conduct the microbial counts, $30 \mathrm{~g}$ of sample was transferred into sterile homogenization bags, suspended $1: 10$ (wt/vol) in a peptone physiological salt solution ( $1 \mathrm{~g}$ of neutralized bacteriological peptone and $9 \mathrm{~g}$ of sodium chloride/L), and homogenized for $4 \mathrm{~min}$ in a laboratory stomacher blender. The dilution was also prepared at a 1:4 sample to peptone physiological salt solution ratio for the clostridial spore count of the core silages. The serial dilutions were prepared and mold and yeast numbers were determined using the pour plate technique with $40.0 \mathrm{~g} / \mathrm{L}$ of yeast extract glucose chloramphenicol agar (Difco, West Molesey, Surrey, UK) after incubation at $25^{\circ} \mathrm{C}$ for 3 and $5 \mathrm{~d}$ for yeast and mold, respectively. The mold and yeast colony forming units were enumerated separately, according to their macromorphological features. The mean count of the duplicate subsamples was recorded for the total yeasts and molds on plates that yielded 10 to $100 \mathrm{cfu} /$ Petri dish.

The clostridia spore concentration was determined using the most probable number (MPN) procedure. A serial 10-fold dilution was prepared in a ringer solution (Oxoid Ltd., Hampshire, UK). Tubes from each dilution step, containing $9 \mathrm{~mL}$ of sterilized reinforced Clostridium medium (Merck, Darmstadt, Germany) supplemented with sodium lactate $60 \%$ (wt/wt) syrup $(25 \mathrm{~mL} / \mathrm{L})$, agar $(15 \mathrm{~g} / \mathrm{L})$, and $0.2 \mathrm{~g} / \mathrm{L}$ of D-cycloserine (added through $0.2 \mu \mathrm{m}$-sterile filter; Jonsson, 1990), were each inoculated with $1 \mathrm{~mL}$. The tubes were heated in a water bath for $10 \mathrm{~min}$ at $80^{\circ} \mathrm{C}$ to inactivate the vegetative cells and to trigger the spore germination. The tubes were sealed with paraffin and incubated for $7 \mathrm{~d}$ at $37^{\circ} \mathrm{C}$. A tube scored positive if it exhibited abundant gas formation after incubation.

\section{Statistical Analysis}

All the microbial counts were $\log _{10}$ transformed to obtain log-normal distributed data. To calculate the averages, the values below the detection level (detection levels: 15 clostridia spores/g, 10 yeast/g, and 10 mold/g) were assigned a value corresponding to half of the detection level (i.e., 7.5 clostridia spores/g, 5 yeast/g, and 5 mold/g; Tabacco et al., 2009).

To evaluate statistical significance between the various locations of the silo face, the data were analyzed using the ANOVA procedure and significant differences among means were determined by Tukey multiple range test. Pearson correlation coefficients of corn silage chemical and microbiological composition, difference between silage temperature and reference temperature of the core of the silage measured at $400 \mathrm{~mm}$ behind the silage working face $\left(\mathbf{d T}_{\text {ref40 }}\right)$, and temperature of the silage sample and their level of significance were determined. Data of $\mathrm{pH}$, yeast count, mold count, and lactic acid content were regressed on $\mathrm{dT}_{\text {ref40 }}$, visibly molded spot (MOLD_SPO; $1=$ silage visibly molded, $0=$ no visible mold), and $\mathrm{dT}_{\text {ref } 40} \times$ MOLD-SPO as independent variables. Multiple regression analysis was performed using the stepwise selection procedure of SPSS (SPSS Inc., Chicago, IL) to select the best regression model at $P<0.05$. The best equation for each parameter was selected using the coefficient of determination and root mean square error. All the reported determination coefficients $\left(\mathrm{R}^{2}\right)$ were adjusted for degrees of freedom. Unless stated, all regression coefficients were significant at $P<0.05$. All the above statistical analyses were performed using SPSS (version 16 for Windows, SPSS Inc.).

The triangulation gridding method with a linear interpolation option of Surface Mapping System (version 6.0.3; Golden Software, 1995) was used to interpolate the temperature and the $\mathrm{dT}_{\text {ref }}$ of the silage face values. Gridding is the process of using original data points (observations) in an XYZ data file to generate calculated data points on a regularly spaced grid. The interpolation schemes estimate the value of the surface at locations where no original data exists, on the basis of the known data values. The Surface Mapping System program was then used to generate the grid temperature contour map of the silage face. The silage surface areas with $\mathrm{dT}_{\text {ref }}>5^{\circ} \mathrm{C}$ or $>10^{\circ} \mathrm{C}$ were estimated using the option grid volume of the Surface Mapping System program.

\section{RESULTS}

The mean chemical and microbial composition from the core, peripheral areas, and molded spots of the silages are reported in Table 1 . The cores were characterized by a DM content ranging from 26.2 to $41.4 \%$, with a mean value of $34.3 \%$, an $\mathrm{a}_{\mathrm{w}}$ of 0.981 , and a $\mathrm{pH}$ of 3.64. The lactic acid ranged from 1.44 to $8.98 \%$ of $\mathrm{DM}$, and the acetic acid from 0.17 to $5.48 \%$ of $\mathrm{DM}$, but the butyric acid was always below the detection limit. The microbial characteristics of the core resulted in a 
Table 1. Mean values (ranges in parentheses) of chemical and microbiological characteristics from the core, peripheral areas, and molded spots of corn silages observed in the farm survey $(\mathrm{n}=369)$

\begin{tabular}{|c|c|c|c|c|c|}
\hline Item $^{1}$ & Silage core $(\mathrm{n}=108)$ & Peripheral areas $(\mathrm{n}=108)$ & Molded spots $(\mathrm{n}=153)$ & SE & $P$-value \\
\hline Water activity & $0.981(0.960-0.990)$ & $0.988(0.963-1.00)$ & $0.993(0.970-1.00)$ & 0.000761 & $<0.001$ \\
\hline Mold $(\log \mathrm{cfu} / \mathrm{g})$ & $1.76^{\mathrm{c}}(<1.00-4.04)$ & $3.71^{\mathrm{b}}(<1.00-6.65)$ & $8.00^{\mathrm{a}}(5.70-9.40)$ & 0.160 & $<0.001$ \\
\hline Clostridia spores (log MPN/g) & $1.36^{\mathrm{c}}(<1.18-2.36)$ & $2.75^{\mathrm{b}}(<1.18-6.46)$ & $5.08^{\mathrm{a}}(1.48-7.04)$ & 0.241 & $<0.001$ \\
\hline Sample temperature $\left({ }^{\circ} \mathrm{C}\right)$ & $18.6^{\mathrm{c}}(12.0-22.9)$ & $30.6^{\mathrm{b}}(7.6-51.8)$ & $35.4^{\mathrm{a}}(12.4-54.5)$ & 0.634 & $<0.001$ \\
\hline Lactic acid (\% DM) & $5.45^{\mathrm{a}}(1.44-8.98)$ & $2.91^{\mathrm{b}}(<0.001-7.09)$ & $0.02^{\mathrm{c}}(<0.001-0.85)$ & 0.149 & $<0.001$ \\
\hline Acetic acid (\% DM) & $1.67^{\mathrm{a}}(0.17-5.68)$ & $1.63^{\mathrm{a}}(<0.001-6.16)$ & $0.02^{\mathrm{b}}(<0.001-0.72)$ & 0.0626 & $<0.001$ \\
\hline Butyric acid (\% DM $)$ & $<0.001^{\mathrm{b}}$ & $0.03^{\mathrm{a}}(<0.001-0.64)$ & $0.02^{\mathrm{a}}(<0.001-0.24)$ & 0.00589 & 0.002 \\
\hline
\end{tabular}

${ }^{\mathrm{a}-\mathrm{c}}$ Means within a row with different superscripts differ $(P<0.05)$.

${ }^{1} \mathrm{MPN}=$ most probable number; $\mathrm{dT}_{\mathrm{ref} 40}=$ difference between silage temperature and reference temperature of the core of the silage measured at $400 \mathrm{~mm}$ behind the silage working face.

mean yeast count of $2.93 \mathrm{log} \mathrm{cfu} / \mathrm{g}$, a mold count of $1.76 \mathrm{log} \mathrm{cfu} / \mathrm{g}$, and a clostridial spore content of 1.36 $\log \mathrm{MPN} / \mathrm{g}$. The $\mathrm{dT}_{\mathrm{ref} 40}$ of the core silages ranged from -5.9 to 0.9 , with a mean value of around zero.

The samples from the peripheral areas with no visible molds presented chemical values that ranged from values similar to those of the core to values that are characteristic of deeply altered silage $(\mathrm{pH}$ as high as 8.71, absence of lactic and acetic acids, and presence of butyric acid, with values of up to $0.64 \%$ on DM). As expected, the samples from the molded spots presented deeply altered chemical and microbial profiles, with a mean $\mathrm{pH}$ of 6.84 , an $\mathrm{a}_{\mathrm{w}}$ of 0.993 , yeast as high as 6 $\log \mathrm{cfu} / \mathrm{g}$, mold of around $8 \mathrm{log} \mathrm{cfu} / \mathrm{g}$, and clostridial spores from 1.48 to $7.04 \log \mathrm{MPN} / \mathrm{g}$. Furthermore, the microbial activity of the deteriorated silage altered the acid contents, with an absence of lactic and acetic acids and a butyric acid content that ranged from $<0.001$ to $0.24 \%$ of DM. The correlations between the $\mathrm{dT}_{\text {ref } 40}$ and chemical and microbial composition of the silage samples are reported in Table 2 . The $\mathrm{dT}_{\text {ref40 }}$ showed positive correlation with $\mathrm{pH}, \mathrm{a}_{\mathrm{w}}$, yeast count, mold count, and clostridia spores, whereas it was negatively correlated with lactic acid, acetic acid, and nitrate concentration. Other silage variables were variously intercorrelated.

The silage temperature in the core was $18.6^{\circ} \mathrm{C}$ on average, with values ranging from 12.0 to $22.9^{\circ} \mathrm{C}$. Higher values were observed in the peripheral areas and in the molded spots of the silo, with temperatures of up to $54.5^{\circ} \mathrm{C}$. The temperature of the silage core in the studied silos and the ambient temperatures are reported in Figure 1 as a function of the sampling time. The reference temperature averages measured in the central zone of the silos are reported in Figure 2 as a function of depth from the feed-out face for winter, spring, and summer consumptions. The temperatures were almost constant for all the seasons below $400 \mathrm{~mm}$ from the working face, with lower values observed over the spring period. The $\mathrm{T}_{\text {ref }}$ measured at a depth of $400 \mathrm{~mm}\left(\mathbf{T}_{\text {ref40 }}\right)$ was used as a reference for the method and ranged from 12.4 to $25.7^{\circ} \mathrm{C}$, with a mean value of $21.5,16.4$, and $19.5^{\circ} \mathrm{C}$ in winter, spring, and summer, respectively.

Table 2. Pearson correlation coefficients of corn silage chemical and microbiological composition and difference between silage temperature and reference temperature of the core of the silage measured at $400 \mathrm{~mm}$ behind the silage working face $\left(\mathrm{dT}_{\text {ref40 }}\right)(\mathrm{n}=369)$

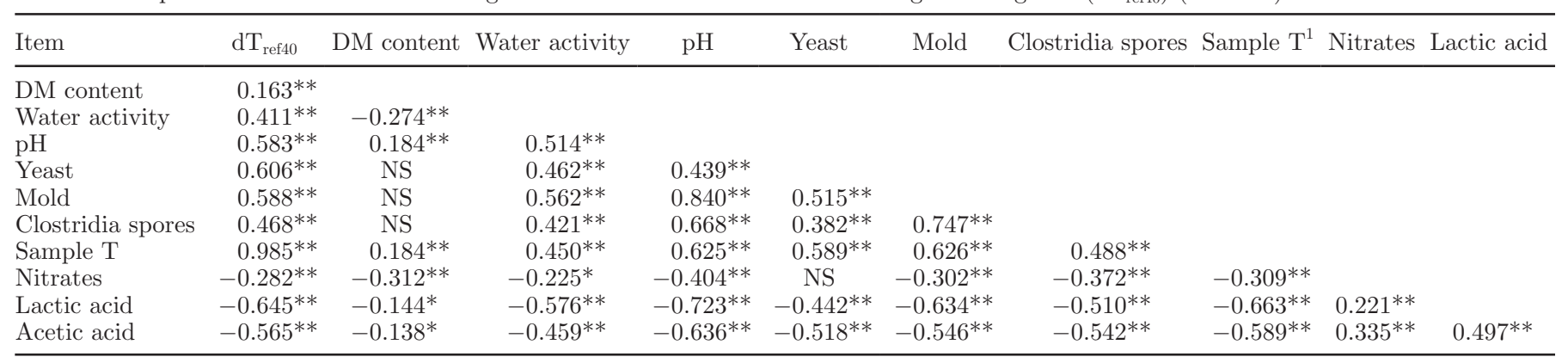

${ }^{1}$ Sample $\mathrm{T}=$ sample temperature.

${ }^{*} P<0.05 ;{ }^{* *} P<0.01 ; \mathrm{NS}=P>0.05$. 


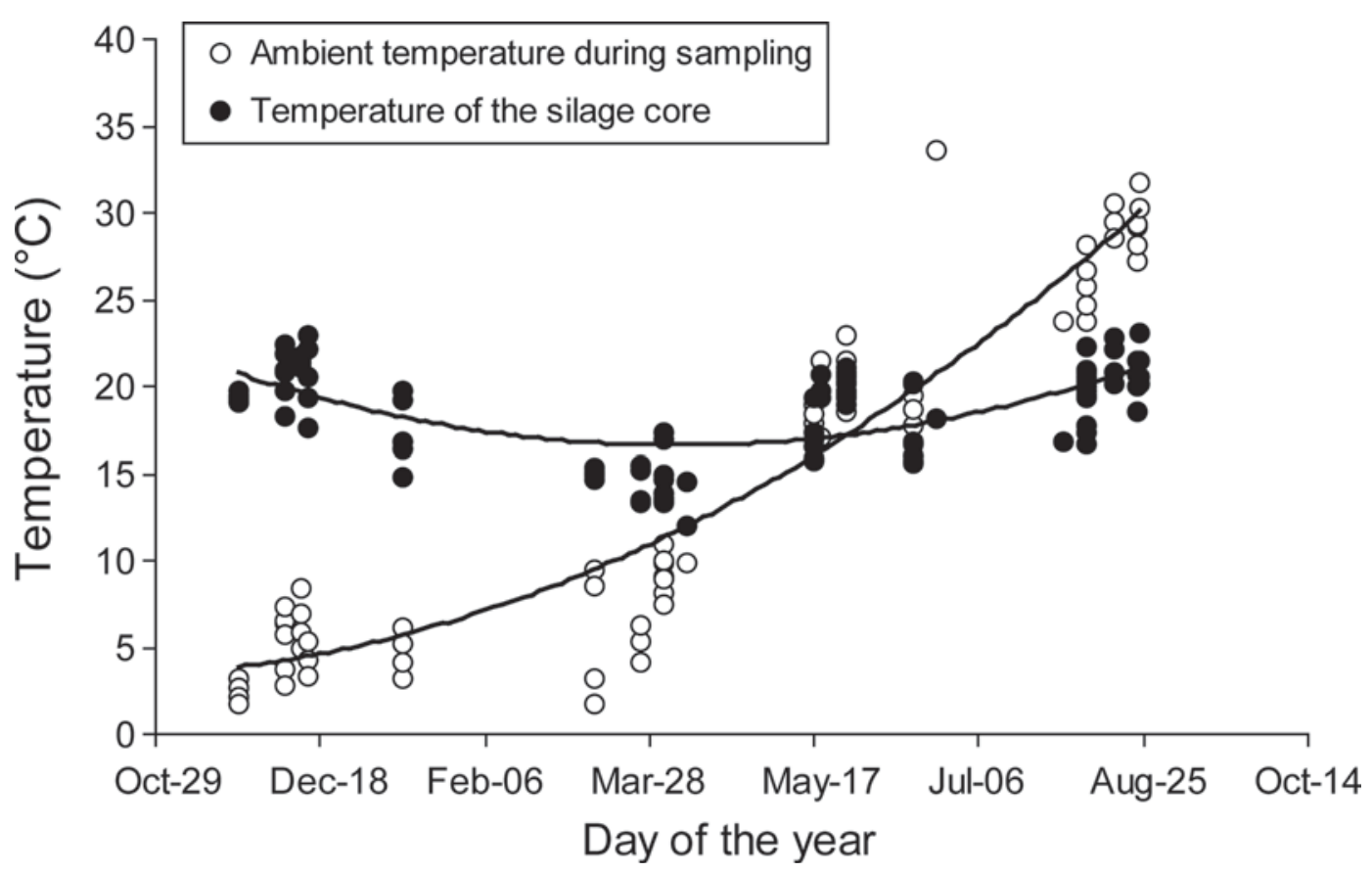

Figure 1. Temperature of the silage core and ambient temperature in the studied silos as a function of the sampling time.

As a consequence, the calculated difference between silage sample temperature and $\mathrm{T}_{\text {ref40 }}\left(\mathrm{dT}_{\text {ref40 }}\right)$ was 9.9 and $13.3^{\circ} \mathrm{C}$ on average for the silage from the peripheral areas and from the molded spots, respectively, whereas it was close to $0^{\circ} \mathrm{C}$ in the silage core (Table 1 ).
The relationships between $\mathrm{dT}_{\mathrm{ref} 40}$ and $\mathrm{pH}$, the yeast count, and the mold count are reported in Figures 3, 4 , and 5 , where all the data from the survey have been pooled together. The regression equations that describe the relationships between $\mathrm{pH}$, yeast count, mold count,

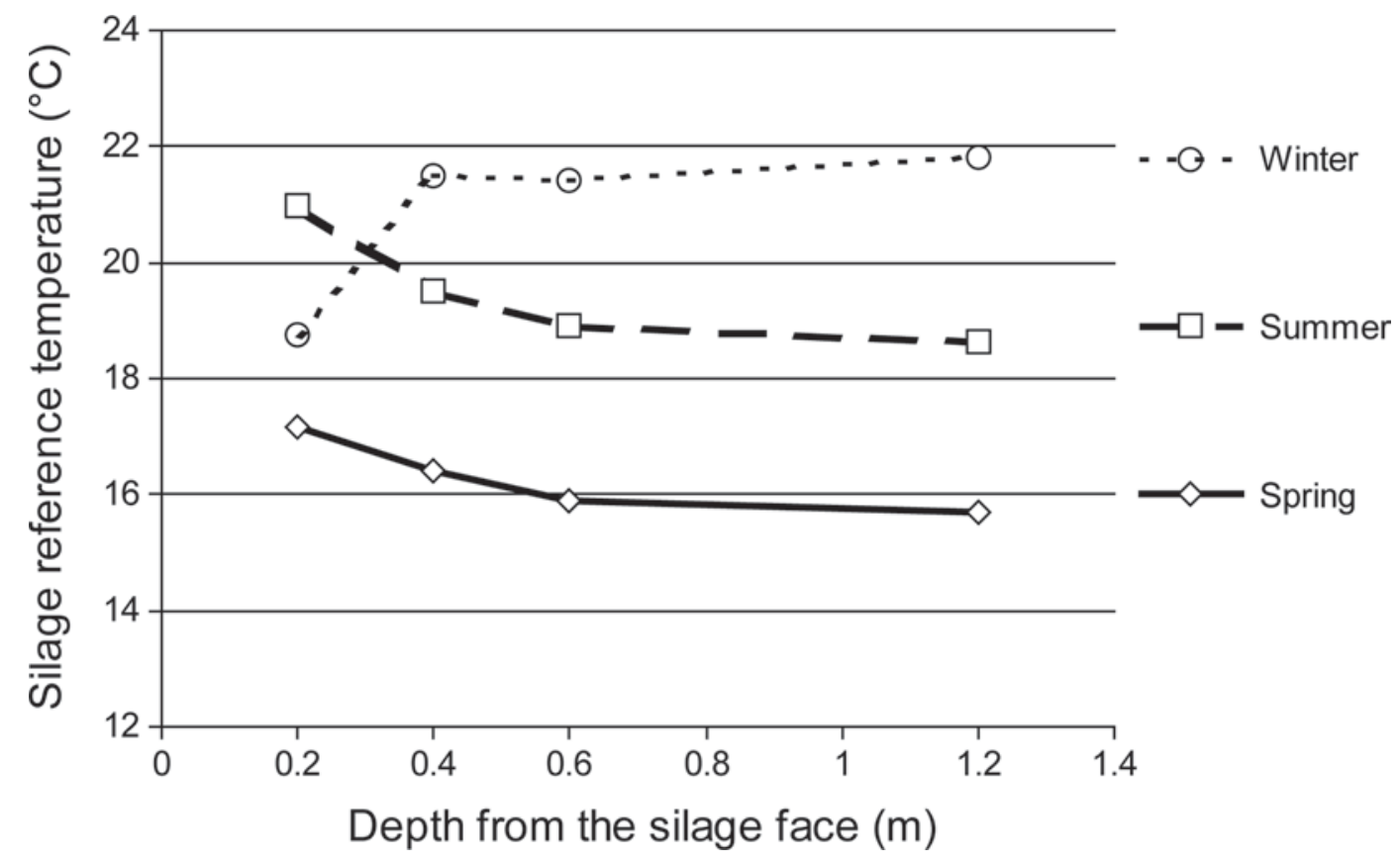

Figure 2. Average reference temperature $\left(\mathrm{T}_{\text {ref }}\right)$ profiles in the studied silos as a function of depth from the feed-out face in winter, spring, and summer periods. 

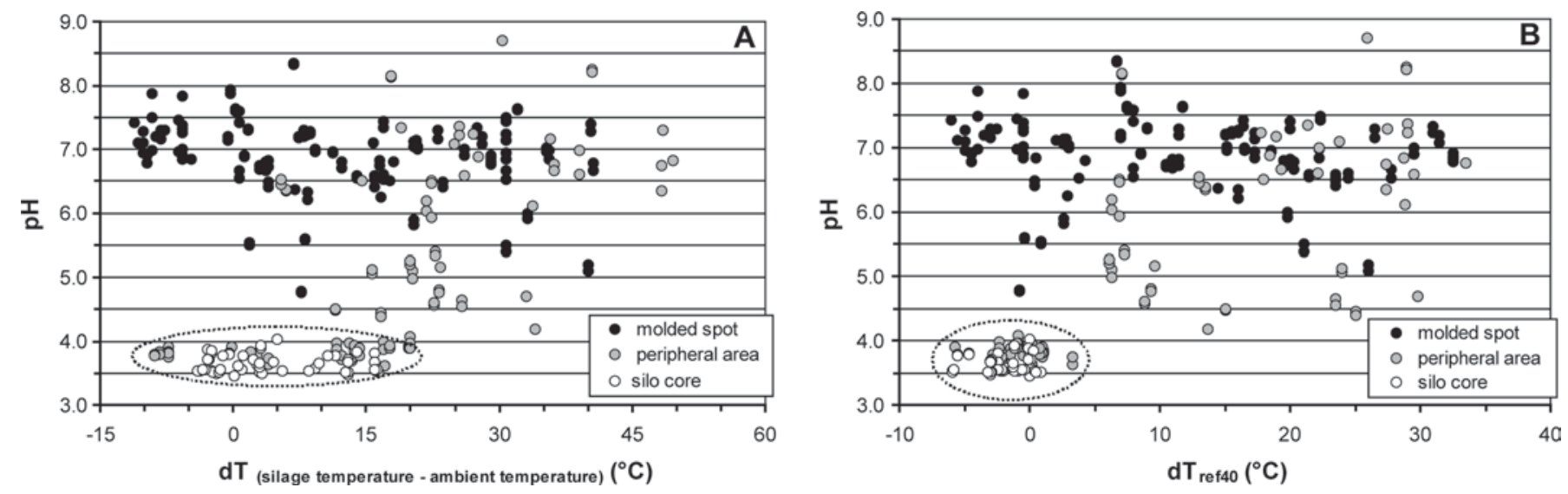

Figure 3. pH related to A) difference between silage temperature and ambient temperature (dT) and B) difference between silage temperature and reference temperature of the core of the silage measured at $400 \mathrm{~mm}$ behind the silage working face $\left(\mathrm{dT}_{\mathrm{ref} 40}\right)$ in the studied farm corn silages. The samples grouped in the dotted circle are well-conserved silages.

and lactic acid and $\mathrm{dT}_{\text {ref40 }}$, MOLD-SPO, and $\mathrm{dT}_{\text {ref40 }} \times$ MOLD-SPO as independent variables are presented in Table 3. The core samples always showed a $\mathrm{pH}$ below 4.0 and a $\mathrm{dT}_{\text {ref } 40}$ below $2^{\circ} \mathrm{C}$, whereas the silages from the peripheral areas were split into 2 groups, one that had a $\mathrm{pH}$ lower than 4 and a $\mathrm{dT}_{\mathrm{ref4} 4}$ lower than $3.5^{\circ} \mathrm{C}$ $(53 \%)$ and one that had a $\mathrm{pH}$ higher than 4 and a $\mathrm{dT}_{\text {ref40 }}$ higher than $5^{\circ} \mathrm{C}(47 \%)$. A positive $\mathrm{dT}_{\text {ref } 40}$ higher than $5^{\circ} \mathrm{C}$ was associated with a $\mathrm{pH}$ higher than 4.5 in most of the silages from the peripheral areas (48/51 samples) and in all the silage from moldy spots. Several samples from visible moldy spots (39/153) presented an altered $\mathrm{pH}$ with a $\mathrm{dT}_{\text {ref } 40}$ close to zero. Furthermore, a positive $\mathrm{dT}_{\text {ref } 40}$ higher than $5{ }^{\circ} \mathrm{C}$ corresponded to a yeast count higher than $5 \mathrm{log} \mathrm{cfu} / \mathrm{g}$ in most of the silages from the peripheral areas (51/55 samples) and from almost all the silages from the molded spots $(109 / 113)$. The yeast count tended to decrease for molded spots with $\mathrm{dT}_{\text {ref40 }}$ lower than $5^{\circ} \mathrm{C}$. The samples with visible mold had a mold count higher than $6 \mathrm{log} \mathrm{cfu} / \mathrm{g}$ in almost all the samples. To partially explain the further $\mathrm{pH}$ and mold count increase with the progressive cooling of visible molded silage, the MOLD_SPO and $\mathrm{dT}_{\text {ref } 40} \times$ MOLD_SPO variables were tested in the regression analysis. The coefficient of determination of the regression equations for $\mathrm{pH}$ and mold count greatly increased from 0.414 and 0.263 (data not shown), when only $\mathrm{dT}_{\text {ref } 40}$ was used, to 0.820 and 0.843 , respectively.

The relationship between the $\mathrm{pH}$ and lactic acid concentration is reported in Figure 6 and the relative regression equation is given in Table 3, where all the data from the survey are pooled together. It is clear that when the $\mathrm{pH}$ is higher than 4.5 , the lactic acid is below $1.0 \%$ on DM. All except for 4 of the molded
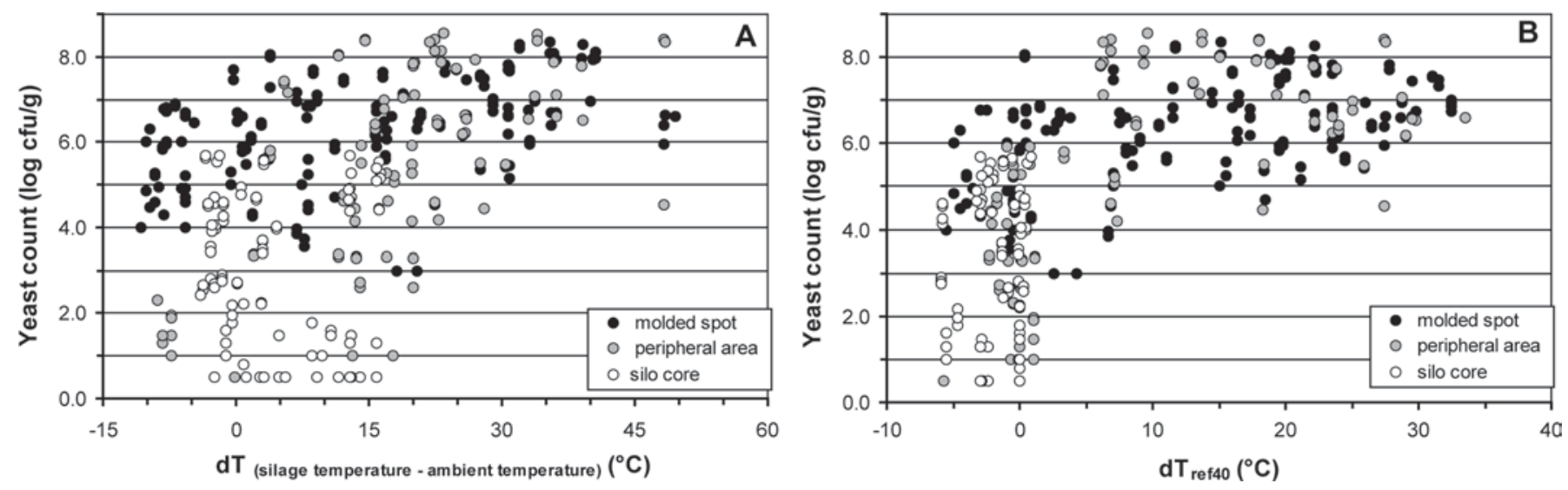

Figure 4. Yeast count related to A) difference between silage temperature and ambient temperature (dT) and B) difference between silage temperature and reference temperature of the core of the silage measured at $400 \mathrm{~mm}$ behind the silage working face $\left(\mathrm{dT}_{\text {ref } 40}\right)$ in the studied farm corn silages. 
Table 3. Regression models of $\mathrm{pH}$, yeast count, mold count, and lactic acid on $\mathrm{dT}_{\text {ref } 40},{ }^{1}$ and $\mathrm{MOLD}_{-} \mathrm{SPO}^{2}$ as independent variables $(\mathrm{n}=369)$

\begin{tabular}{|c|c|c|c|}
\hline Equation no. & Equation model & Adjusted $\mathrm{R}^{2}$ & $\mathrm{RMSE}^{3}$ \\
\hline 1 & $\mathrm{pH}=+2.999 \times$ MOLD_SPO $+0.105 \times \mathrm{dT}_{\mathrm{ref40}}-0.111 \times \mathrm{MOLD} \_\mathrm{SPO} \times \mathrm{dT}_{\mathrm{ref40}}+3.937^{4}$ & 0.820 & 0.685 \\
\hline 2 & Yeast count $(\log \mathrm{cfu} / \mathrm{g})=+0.232 \times \mathrm{dT}_{\text {ref40 }}-0.00510 \times \mathrm{dT}_{\text {ref40 }}{ }^{2}+0.997 \times$ MOLD_SPO +3.728 & 0.505 & 1.62 \\
\hline 3 & Mold count $=+6.120 \times$ MOLD_SPO $+0.104 \times \mathrm{dT}_{\text {ref40 }}-0.133 \times$ MOLD_SPO $\times \mathrm{dT}_{\text {ref40 }}+2.270$ & 0.843 & 1.19 \\
\hline
\end{tabular}

${ }^{1} \mathrm{dT}_{\text {ref } 40}=$ difference between silage temperature and reference temperature of the core of the silage measured at $400 \mathrm{~mm}$ behind the silage working face.

${ }^{2}$ MOLD_SPO: $1=$ silage visibly molded, $0=$ no visible mold .

${ }^{3} \mathrm{RMSE}=$ root mean square error.

${ }^{4}$ All coefficients are significantly different from zero $(P<0.05)$.

samples presented a lactic acid content below the detection limit.

The thermography and the $\mathrm{dT}_{\text {ref } 40}$ contour maps of 2 silage faces of 2 surveyed bunker silos are reported in Figure 7 as an example of the application of silage temperature measurement on farms. The bunker in part A of the figure did not show any visibly molded spots and only a small area with a $\mathrm{dT}_{\text {ref } 40}$ higher than $5^{\circ} \mathrm{C}$, which involved $3.7 \%$ of the total silage surface, whereas the bunker in part B had $23.2 \%$ of its surface aerobically deteriorated, with $\mathrm{dT}_{\text {ref } 40}$ higher than $5^{\circ} \mathrm{C}$ or spots with visible mold.

\section{DISCUSSION}

It has long been recognized that the presence of air produces deleterious effects on silage (Beck and Gross, 1964; Woolford, 1990) and oxygen enables various aerobic spoilage microorganisms, which survive in the anaerobic phase of ensiling, to become active and to multiply, causing aerobic deterioration (Woolford, 1990).
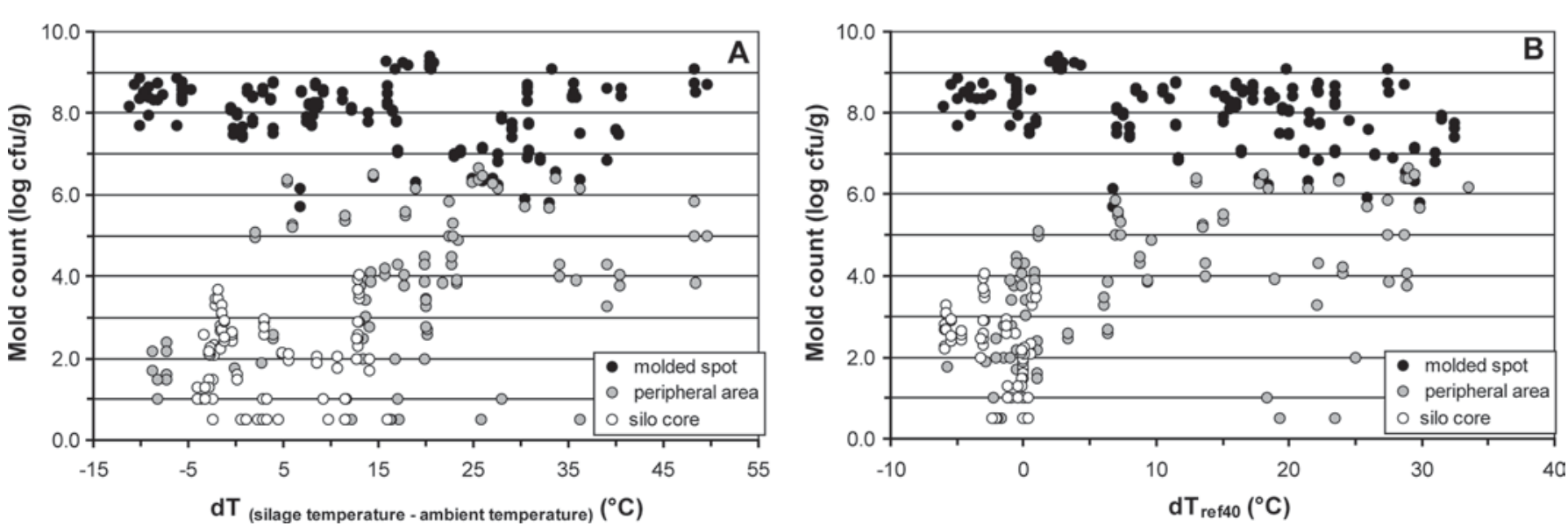

Figure 5. Mold count related to A) difference between silage temperature and ambient temperature (dT) and B) difference between silage temperature and reference temperature of the core of the silage measured at $400 \mathrm{~mm}$ behind the silage working face $\left(\mathrm{dT}_{\text {ref } 40}\right)$ in the studied farm corn silages.

Journal of Dairy Science Vol. 93 No. 6, 2010
A method to evaluate the incoming of aerobic deterioration in laboratory-scale experiments was first proposed in the 1970s by German researchers (Pahlow and Muck, 2009) and was developed in the subsequent years until it became a standardized methodology (Ranjit and Kung, 2000) that is today adopted in all experiments set up to establish the aerobic stability of silages under different conditions (i.e., inoculum, additives, and crop characteristics). In short, this method, which is always performed under well-controlled laboratory conditions, involves continuous temperature measurements of samples placed inside insulated polystyrene boxes and measurement of the ambient temperature as the reference value. Aerobic stability is defined as the number of hours that silage is exposed to air before a $2^{\circ} \mathrm{C}$ increase in temperature above the ambient temperature. It is well known that, during aerobic stability tests on corn silages, when the temperature starts to increase it rapidly reaches a peak in less than $24 \mathrm{~h}$ because lactateassimilating yeasts, which are considered the primary initiators of aerobic spoilage, are capable of rapid growth in the presence of oxygen (Lowes et al., 2000; Tabacco 


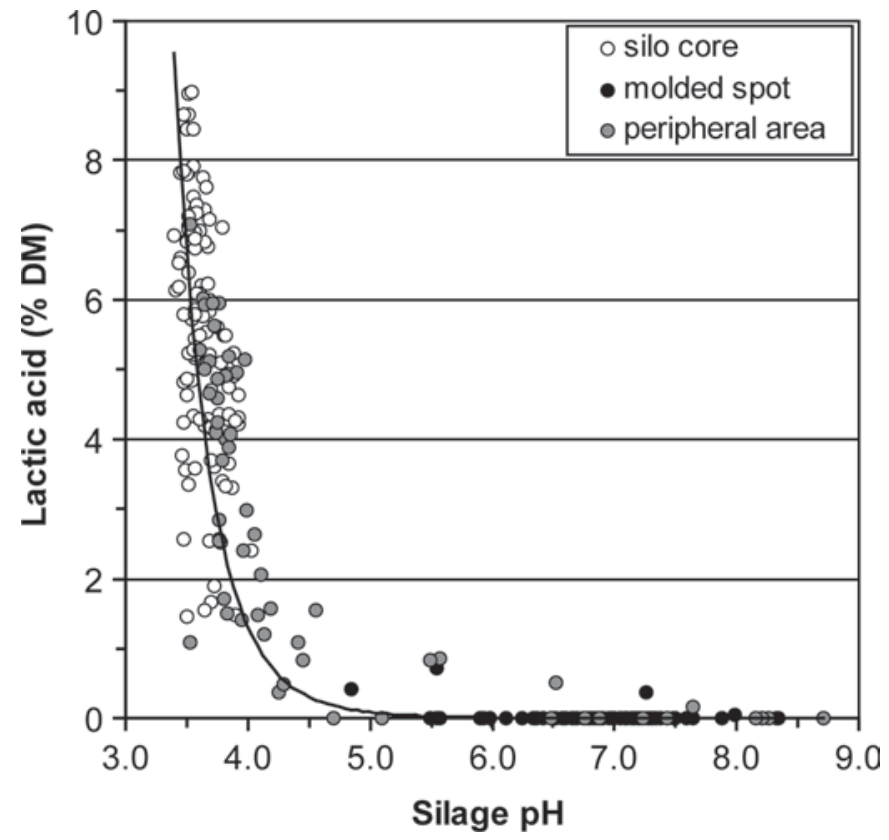

Figure 6. Relationship between lactic acid and silage $\mathrm{pH}$ in the studied farm corn silages. Regression equation: lactic acid (\% DM) $=3.018 \times 10^{7} \times \mathrm{pH}^{-12.23} ; \mathrm{R}^{2}=0.895$ and root mean square error $=$ 1.34 .

et al., 2009). Honig and Woolford (1980) stated that because the oxidation process is accompanied by the evolution of heat, an increase in temperature is a convenient indicator of the extent and intensity of aerobic deterioration in both experimental and practical conditions. A first attempt to establish which area of the silo is subject to aerobic deterioration at a farm level by the mean of temperature measurement was made by Ruppel et al. (1995). These authors measured temperatures inside storage silage during feed-out at depths of 200 $\mathrm{mm}$ at various locations across the working face and the ambient temperatures at the same time. They then used silage temperature above ambient temperature as an index of heating associated with aerobic deterioration $(\mathbf{d T})$. The main problem of this method is that the ambient temperature is not always a suitable reference, especially in temperate environments where it is subject to seasonal and daily fluctuations (i.e., up to $25^{\circ} \mathrm{C}$ in spring and fall in northern Italy). Our results indicate that when the ambient temperature is used as the reference value to calculate the dT, it gives biased indications of the healthy status of the silage, with more than $35 \%$ of the core samples having dT higher than $5^{\circ} \mathrm{C}$ without showing any evident alteration in terms of $\mathrm{pH}$ (Figure 3A).

In our survey, the silage temperature of the core samples taken $200 \mathrm{~mm}$ behind the silage face ranged from 12.0 to $22.9^{\circ} \mathrm{C}$, with measured ambient temperatures ranging from 2.2 to $33.6^{\circ} \mathrm{C}$. The highest temperatures of the silage core were observed close to the harvesting season, in fall and winter, whereas the coldest temperatures were measured at the beginning of spring and early summer. This is because of the progressive
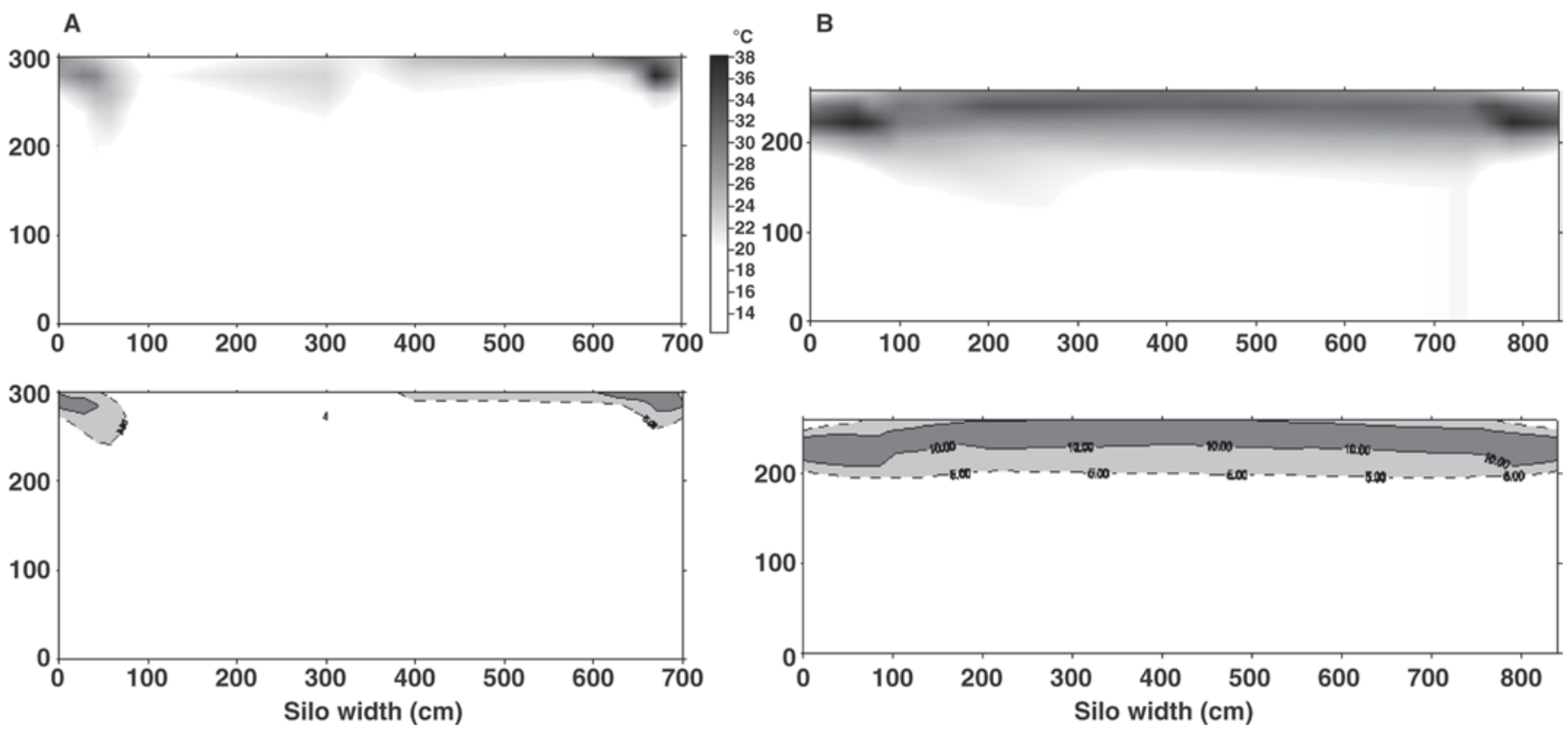

Figure 7. Examples of thermal images (upper panel) and calculated isothermal contour map (lower panel) of $\mathrm{dT}_{\text {ref40 }}>5^{\circ} \mathrm{C}($ light gray) and $\mathrm{dT}_{\text {ref40 }}>10^{\circ} \mathrm{C}$ (dark gray) of the working face of 2 of the surveyed bunker silos. A) Bunker with no visible spoiled areas. Total silos surface 21 $\mathrm{m}^{2}(3.0 \mathrm{~m} \times 7.0 \mathrm{~m}), 0.78 \mathrm{~m}^{2}$ aerobic spoiled surface with $\mathrm{dT}_{\text {ref } 40}>5^{\circ} \mathrm{C}$, and $0.17 \mathrm{~m}^{2}$ with $\mathrm{dT}_{\text {ref } 40}>10^{\circ} \mathrm{C}$. B) Bunker with visible molded spots. Total silos surface $21.8 \mathrm{~m}^{2}(2.6 \mathrm{~m} \times 8.4 \mathrm{~m}), 5.06 \mathrm{~m}^{2}$ aerobic spoiled surface with $\mathrm{dT}_{\text {ref40 }}>5^{\circ} \mathrm{C}$, and $2.46 \mathrm{~m}^{2}$ with $\mathrm{dT}_{\text {ref40 }}>10^{\circ} \mathrm{C}$. 
cooling of the silage mass in winter, as also observed by Green et al. (2009) on corn silage in Denmark and by Williams et al. (1997) on grass silage in the United Kingdom. Muck and Huhnke (1995) found similar results in Wisconsin, studying air movement in bunker silos and subsequent aerobic deterioration at the silage face. These authors observed that the temperature of a winter corn silage in the core increased from 12.5 to $20^{\circ} \mathrm{C}$ with increasing depth from the face, whereas in a summer silo temperature decreased with increasing depth from 25 to $20^{\circ} \mathrm{C}$. It is interesting to observe from these data that the temperature of the silage core remained almost constant from a depth of 400 to $1,000 \mathrm{~mm}$, with temperatures around $20^{\circ} \mathrm{C}$ both for winter and summer silos. For these reasons, steam could be released from the core of the silo in temperate environments during the winter season because of the difference between the retained heat (produced by respiration during silo filling and to a lesser extent by fermentation processes) and the ambient temperature. Therefore, the presence of steam from the core of the silo does not always mean that silage is deteriorating (Borreani and Tabacco, 2007). From our data, it is evident that ambient temperature influences the temperature of the core of the silage only to a depth of $200 \mathrm{~mm}$ from the feed-out face, whereas months are necessary to detect temperature variations of aerobically stable silage below $400 \mathrm{~mm}$ from the silo surface (seasonal variations; Figure 2). For these reasons, we suggest that the $T_{\text {ref }}$ measured at a depth of $400 \mathrm{~mm}\left(\mathrm{~T}_{\text {ref40 }}\right)$ could be assumed as a robust reference value to calculate the $\mathrm{dT}_{\text {ref } 40}$ relative to different locations of the feed-out face of the silages. The temperatures of the peripheral areas and of the molded spots of the surveyed silages were very high $\left(>30^{\circ} \mathrm{C}\right)$ in more than $55 \%$ of the samples. This is in agreement with data reported by Ashbell and Lisker (1988) and by Ruppel et al. (1995), who found higher temperatures in the upper part of the silages near the walls, which are difficult to seal properly. The method proposed here allows a $\mathrm{dT}_{\text {ref40 }}$ to be calculated for each silage sample, which can indicate the status of the silage and any silage zone of the working face without visible mold to be classified as aerobically stable or with ongoing aerobic deterioration.

Lactic acid and water-soluble carbohydrates are the main sources of energy for the microorganisms involved in aerobic deterioration. The oxidation of these nutrients results in the production of carbon dioxide and water, with the evolution of heat (McDonald et al., 1991). The release of water during the oxidation process also increases the $\mathrm{a}_{\mathrm{w}}$ of the silages that, together with lactic acid depletion, leads to a less inhibiting environment for microbial activity. When well-fermented silages with low values of residual sugars are considered (such as corn silage; Weinberg et al., 2001), the main oxidized product is likely to be lactic acid. With the complete oxidation of lactic acid $(15.16 \mathrm{~kJ} / \mathrm{g})$, the temperature could increase in the silage mass to $70^{\circ} \mathrm{C}$, assuming a specific heat capacity of $1.89 \mathrm{~kJ} / \mathrm{kg} /{ }^{\circ} \mathrm{C}$ for the silage DM and no loss of heat to the atmosphere (McDonald and Whittenbury, 1973). In most practical situations, a part of the heat produced through oxidation will be dissipated into the atmosphere, although temperatures of up to $54.5^{\circ} \mathrm{C}$ have been recorded in the peripheral areas and in the molded spots of the studied silages in our experiment. These data are in agreement with previous studies on corn silages (Bolsen et al., 1993; Ruppel et al., 1995). When the calculated $\mathrm{dT}_{\text {ref40 }}$ of the peripheral areas and of the molded spots was higher than $5^{\circ} \mathrm{C}$, the yeast count was higher than $5 \log \mathrm{cfu} / \mathrm{g}$ and the $\mathrm{pH}$ was higher than 4.5 , whereas when $\mathrm{dT}_{\text {ref } 40}$ was higher than $10^{\circ} \mathrm{C}$, the mold count also showed values higher than $4 \log \mathrm{cfu} / \mathrm{g}$. Furthermore, when the absolute temperature increased to over $35^{\circ} \mathrm{C}$, the $\mathrm{dT}_{\text {ref } 40}$ was higher than $10^{\circ} \mathrm{C}$, and nitrate concentration was lower than $200 \mathrm{mg} / \mathrm{kg}$ of fresh matter, it was possible to find a high spore clostridia count, as reported by Borreani and Tabacco (2008).

Because the microbial population increased during aerobic deterioration in an exponential manner, the silage from the peripheral areas and from the molded spots had the potential of contaminating feed-out silage to a great extent, even when it was included in very small amounts, whereas the fermentative profile could be unaffected or slightly modified. From a practical perspective, the strategy of diluting contaminated silage with other mold-free feeds or silage is not a healthy solution, especially for milking dairy cows or young cows. General recommendations suggest that silages with $10^{4} \mathrm{cfu} / \mathrm{g}$ are generally safe to feed to $\mathrm{ru}-$ minants, whereas levels in excess of $5 \times 10^{6}$ to $1 \times 10^{7}$ $\mathrm{cfu} / \mathrm{g}$ should be discarded (Mahanna and Chase, 2003; Chen and Weinberg, 2009). The calculated $\mathrm{dT}_{\mathrm{ref} 40}$ of a silage face should be used to create a map of the whole working face with the aid of mapping system computer programs (e.g., Figure 7) to obtain management indications to help prevent aerobic spoilage and to estimate the quality of the silage fed to animals. Furthermore, if those areas are related to the DM densities of the silages, it is also possible to calculate the amount of deteriorated silage that should be discarded and the economic value of the DM lost.

The data of this research show that increases in temperature at the silo face of farm bunkers are clearly linked to aerobic microbial activity (especially mold growth), and changes of silage $\mathrm{pH}$ and the measurement of the temperature could have applications in alerting farmers to the onset of aerobic deterioration 
and could be useful as an index to identify the invisible altered mass of silage. The evaluation of the extension of the visible molded areas combined with temperature measurements at $200 \mathrm{~mm}$ behind the feed-out face could be used to obtain a good indication of the health status of the silage during consumption. Furthermore, the application of this method could be useful to detect the aerobic deterioration process in its early stages and to quantify the extent of the spoiled areas to correctly discard the spoiled silage and to improve silage management.

\section{ACKNOWLEDGMENTS}

The authors thank Serenella Piano (Dip. Agronomia, Selvicoltura e Gestione del Territorio-University of Turin, Italy) for the chemical and microbiological analyses. This work was funded by the Regione Piemonte, Assessorato Qualità, Ambiente e Agricoltura years 2005-2008 project "Influenza della zona di produzione e del tipo di gestione aziendale sulla qualità del Grana Padano D.O.P. piemontese." Article partially presented at the XVth International Silage Conference, Madison, Wisconsin, July 27-29, 2009. The 2 authors contributed equally to the work described in this paper.

\section{REFERENCES}

Ashbell, G., and N. Lisker. 1988. Aerobic deterioration in maize silage stored in a bunker silos under farm conditions in a subtropical climate. J. Sci. Food Agric. 45:307-315.

Ashbell, G., and Z. G. Weinberg. 1992. Top silage losses in horizontal silos. Can. J. Eng. 34:171-175.

Beck, T., and F. Gross. 1964. Ursachen der unterschiedlichen haltbarkeit von gärfutter. Wirtschaftseigene Futter 10:298-312.

Bolsen, K. K., J. T. Dickerson, B. E. Brent, R. N. Sonon Jr., B. S. Dalke, C. Lin, and J. E. Boyer Jr. 1993. Rate and extent of top spoilage losses in horizontal silos. J. Dairy Sci. 76:2940-2962.

Borreani, G., and E. Tabacco. 2007. Il Silomais. Guida Pratica. [A Practical Guide for Corn Silage Management]. Agricoltura e Ricerca, Regione Piemonte, L'Artistica Savigliano, Savigliano (CN), Italy.

Borreani, G., and E. Tabacco. 2008. Low permeability to oxygen of a new barrier film prevents outgrowth of butyric acid bacteria in farm corn silage. J. Dairy Sci. 91:4272-4281.

Borreani, G., and E. Tabacco. 2009. Temperature measurements of large scale silo face to assess aerobic deterioration of corn silage on farm. Pages 175-187 in Proc. International Symposium on Forage Quality and Conservation, Sao Pedro, SP, Brazil. FEALQ, Piracicaba, SP, Brazil.

Canale, A., M. E. Valente, and A. Ciotti. 1984. Determination of volatile carboxylic acids $(C 1-C 5)$ and lactic acid in aqueous acid extracts of silage by high performance liquid chromatography. J. Sci. Food Agric. 35:1178-1182.

Chen, Y., and Z. G. Weinberg. 2009. Changes during aerobic exposure of wheat silages. Anim. Feed Sci. Technol. 154:76-82.

Golden Software. 1995. SURFER for Windows. Golden Software Inc., Golden, $\mathrm{CO}$.

Green, O., E. S. Nadimi, V. Blanes-Vidal, R. N. Jørgensen, I. M. L. Drejer Storm, and C. G. Sørensen. 2009. Monitoring and modeling temperature variations inside silage stacks using novel wireless sensor networks. Comput. Electron. Agric. 69:149-157.

Honig, H., and M. K. Woolford. 1980. Changes in silage on exposure to air. Pages $76-87$ in Proc. Occasional Symp. EGF Forage Conservation in the 80's. Brit. Grassl. Soc., Hurley, UK.
Ivanek, R., Y. Gröhn, and M. Wiedmann. 2006. Listeria monocytogenes in multiple habitats and host populations: Review of available data for mathematical modeling. Foodborne Pathog. Dis. 3:319-336.

Jonsson, A. 1990. Enumeration and confirmation of Clostridium tyrobutyricum in silages using neutral red, D-cycloserine, and lactate dehydrogenase activity. J. Dairy Sci. 73:719-725.

Kung, L. Jr., A. C. Sheperd, A. M. Smagala, K. M. Endres, C. A. Bessett, N. K. Ranjit, and J. L. Glancey. 1998. The effect of preservatives based on propionic acid on the fermentation and aerobic stability of corn silage and a total mixed ration. J. Dairy Sci. 81:1322-1330.

Lindgren, S., G. Pahlow, and E. Oldenburg. 2002. Influence of microbes and their metabolites on feed and food quality. Pages 503-511 in Proc. 19th Gen. Meet. EGF, La Rochelle, France. Brit. Grassl. Soc., Reading, UK.

Lowes, K. F., C. A. Shearman, J. Payne, D. MacKenzie, D. B. Archer, R. J. Merry, and M. J. Gasson. 2000. Prevention of yeast spoilage in feed and food by the yeast mycocin HMK. Appl. Environ. Microbiol. 66:1066-1076.

Mahanna, B., and L. E. Chase. 2003. Practical applications and solutions to silage problems. Pages $855-895$ in Silage Science and Technology. Vol. 42. D. R. Buxton, R. E. Muck, and J. H. Harrison, ed. ASA, CSSA, SSSA, Madison, WI.

McDonald, P., A. R. Henderson, and S. J. E. Heron. 1991. The Biochemistry of Silage. 2nd ed. Chalcombe Publications, Bucks, UK.

McDonald, P., and R. Whittenbury. 1973. The ensilage process. Pages 33-60 in Chemistry and Biochemistry of Herbage. Vol. 3. G. W. Butler and R. W. Bailey, ed. Academic Press, NY.

Muck, R. E., and B. J. Holmes. 2000. Factors affecting bunker silo densities. Appl. Eng. Agric. 16:613-619.

Muck, R. E., and R. L. Huhnke. 1995. Oxygen infiltration from horizontal silo unloading practices. Trans. ASAE 95:23-31.

Pahlow, G., and R. E. Muck. 2009. Managing for improved aerobic stability. Pages 77-90 in Proc. 15th Int. Silage Conf., Madison, WI. University of Wisconsin, Madison.

Ranjit, N. K., and L. Kung Jr. 2000. The effect of Lactobacillus buchneri, Lactobacillus plantarum, or a chemical preservative on the fermentation and aerobic stability of corn silage. J. Dairy Sci. $83: 526-535$.

Rees, D. V. H. 1982. The aerobic deterioration of grass silage and its effect on the water-soluble carbohydrate and the associated heat production. J. Sci. Food Agric. 33:499-508.

Ruppel, K. A., R. E. Pitt, L. E. Chase, and D. M. Galton. 1995. Bunker silo management and its relationship to forage preservation on dairy farms. J. Dairy Sci. 78:141-153.

Schindler, F. V., and R. E. Knighton. 1999. Sample preparation for total nitrogen and ${ }^{15} \mathrm{~N}$-ratio analysis by the automated Dumas combustion method. Commun. Soil Sci. Plant Anal. 30:13151324.

Tabacco, E., S. Piano, L. Cavallarin, T. F. Bernardes, and G. Borreani. 2009. Clostridia spore formation during aerobic deterioration of maize and sorghum silages as influenced by Lactobacillus buchneri and Lactobacillus plantarum inoculants. J. Appl. Microbiol. 107:1632-1641.

Vissers, M. M. M., M. C. Te Giffel, F. Driehuis, P. De Jong, and J. M. G. Lankveld. 2007. Minimizing the level of Bacillus cereus spores in farm tank milk. J. Dairy Sci. 90:3286-3293.

Weinberg, Z. G., G. Szakacs, G. Ashbell, and Y. Hen. 2001. The effect of temperature on the ensiling process of corn and wheat. J. Appl. Microbiol. 90:561-566.

Whitlock, L. A., T. J. Wistuba, M. K. Seifers, R. V. Pope, and K. K. Bolsen. 2000. Effect of level of surface-spoiled silage on the nutritive value of corn silage diets. J. Dairy Sci. 83(Suppl. 1):110 (Abstr.)

Wilkinson, J. M. 1999. Silage and animal health. Nat. Toxins 7:221232.

Williams, A. G., R. P. Hoxey, and J. F. Lowe. 1997. Changes in temperature and silo gas composition during ensiling storage and feeding-out grass silage. Grass Forage Sci. 52:176-189.

Woolford, M. K. 1990. The detrimental effect of air on silage. J. Appl. Bacteriol. 68:101-116. 